\title{
A censura ao direito de sonhar em Quarto de despejo, de Carolina Maria de Jesus
}

Luciana Paiva Coronel ${ }^{1}$

\begin{abstract}
Não tenho força física, mas minhas palavras ferem mais do que espada. E as feridas são incicatrizáveis.
\end{abstract}

Carolina Maria de Jesus

Estudar o testemunho significa assumir que aos excluídos cabe falar $e$, além disso, definir seus próprios modos de fazê-lo.

Jaime Ginzburg

Em artigo intitulado "O direito à literatura", o crítico literário Antonio Candido define o acesso à literatura como um dos direitos humanos básicos, indispensável não à sobrevivência física, mas ao pleno desenvolvimento do imaginário. Ressaltando o papel humanizador profundo exercido pelas manifestações literárias em nossa formação individual, Candido advoga a importância do conhecimento das mais variadas formas de expressão literária, sejam elas legitimadas pelo sistema cultural hegemônico, sejam oriundas de movimentos de negação do estado de coisas predominante.

Mesmo no que diz respeito à literatura de forte viés social, o crítico paulista entende que "a eficácia humana é função da eficácia estética", e que, portanto, "o que na literatura age como força humanizadora é a própria literatura, ou seja, a capacidade de criar formas pertinentes" (Candido, 2004, p. 182). São, dessa forma, as palavras organizadas que, sugerindo ao leitor um modelo de ordenamento do mundo, lhe orientam no sentido da compreensão de si e do seu entorno.

Os diários de Carolina Maria de Jesus, publicados no início dos anos 1960 sob o título Quarto de despejo: diário de uma favelada, constituem exemplo cabal da assertiva de Cândido, pois não revelam apenas a palavra de uma mulher pobre, preta, mãe solteira por três vezes, favelada e semianalfabeta. Revelam o talento da autora na reconstrução

\footnotetext{
${ }^{1}$ Doutora em literatura brasileira e professora adjunta da Universidade Federal do Rio Grande (FURG), Rio Grande, RS, Brasil. E-mail: lu.paiva.coronel@gmail.com
} 
textual da rotina de privações sofridas na favela do Canindé, em São Paulo, entre as quais se encontra com frequência a experiência da fome:

27 de maio de 1958 - A tontura da fome é pior do que a do álcool. A tontura do álcool nos impele a cantar. Mas a da fome nos faz tremer. Percebi que é horrível ter só ar dentro do estômago. Comecei a sentir a boca amarga. Pensei: já não basta as amarguras da vida? [...]

O Léon pegou o papel, recibi seis cruzeiros. Pensei em guardar para comprar feijão. Mas vi que não podia porque o meu estômago reclamava e torturava-me.

Resolvi tomar uma média e comprar um pão. Que efeito surpreendente faz a comida no nosso organismo! Eu que antes de comer via o céu, as árvores, as aves, tudo amarelo, depois que comi, tudo normalizou-se aos meus olhos.

A comida no estômago é como combustível nas máquinas. Passei a trabalhar mais depressa. Meu corpo deixou de pesar. [...] Eu tinha a impressão que eu deslizava no espaço. Comecei a sorrir como se eu estivesse presenciando um lindo espetáculo. E haverá espetáculo mais lindo do que ter o que comer? Parece que eu estava comendo pela primeira vez na minha vida (Jesus, 2007, p. 45-46). ${ }^{2}$

Ainda no caso de uma escrita tão próxima à experiência, são os recursos de linguagem que permitem à autora criar uma narrativa contundente acerca da experiência vivida, representando, por exemplo, a fome como uma vertigem amarela. "Quarto de despejo", título do livro, é igualmente uma imagem-síntese capaz de traduzir a sensação de viver em um local onde as pessoas e o lixo se confundem. É nesse cenário, em que "o único perfume que exala [...] é a lama podre, os excrementos e a pinga" (p. 48), que a autora desperta, no dia da Abolição, sentindo-se ainda escravizada em plena era desenvolvimentista dos anos 1950: “Hoje é o dia que comemora a libertação dos escravos. [...] A Vera começou a pedir comida. E eu não tinha. Era a reprise do espetáculo. [...] E assim no dia 13 de maio de 1958 eu lutava contra a escravatura atual - a fome!" (p. 32).

Valendo-se da ironia para sugerir que o pedido de comida da filha configurava um drama encenado diariamente sem a perspectiva de um

\footnotetext{
2 Todos os excertos de Quarto de despejo provêm da edição de 2007, que se encontra nas referências finais do trabalho. Por tal razão, a partir daqui nas citações curtas será fornecido apenas o número da página.
} 
final feliz, Carolina reelabora a dor sentida por meio das palavras, que canalizam para a página o sofrimento, cristalizando-o além de si e do barraco que abriga a cena. Observando que muitas vezes suas crianças roem pedaços de pão duro, ela aborda com humor tema tão grave: "Pensei: para comer estes pães era preciso que eles tivessem dentes elétricos" (p. 41). Mais do que a situação de penúria, chama a atenção do leitor o modo como ela é enfrentada pela mãe aflita, sua capacidade imaginativa, seu dom de rir diante da pior das adversidades.

Muitas são as formas por meio das quais Carolina transfigura a vida na escrita, permitindo aos leitores conhecer o teor conservador e excludente do processo modernizador em curso no país nos anos 50, época em que escrevia. Partindo, por exemplo, da presença específica do pão duro como alimento que não pode ser dispensado, porque não há outro, ela amplia o âmbito de pertencimento desta dureza, que termina por contemplar a rotina completa da vida dos moradores da favela: "Duro é o pão que nós comemos. Dura é a cama que dormimos. Dura é a vida do favelado" (p. 42).

O mesmo tipo de intensificação de sentido é utilizado a propósito da identidade negra compartilhada em família: "Quando puis a comida o João sorriu. Comeram e não aludiram a cor negra do feijão. Porque negra é a nossa vida. Negro é tudo que nos rodeia" (p. 43). Bem menos explorada na narrativa, a negritude constitui tema secundário do universo simbólico de Carolina, pautado centralmente pela problemática da pobreza, mas também pela capacidade surpreendente da autora de desfrutar as poucas boas coisas que a vida podia lhe oferecer:

23 maio de 58: [...] O céu é belo, digno de contemplar porque as nuvens vagueiam e formam paisagens deslumbrantes. As brisas suaves perpassam conduzindo os perfumes das flores. E o astrorei sempre pontual para despontar-se e recluir-se. As aves percorrem o espaço demonstrando contentamento. A noite surge as estrelas cintilantes para adornar o céu azul. Há várias coisas belas no mundo que não é possível descrever-se. Só uma coisa nos entristece: os preços, quando vamos fazer compras. Ofusca todas as belezas que existe (Jesus, 2007, p. 44).

Carolina Maria de Jesus representa assim o forte contraste existente entre a beleza do mundo e a injustiça nele reinante. O encantamento e a tristeza reunidos compõem um quadro de grande força expressiva, que a autora constrói sobriamente, a partir da mera justaposição dos 
elementos opositivos, sem pieguice, sem autocomiseração. Contrariando a concepção vigente de que as dificuldades materiais endurecem a sensibilidade estética, a autora menciona mais de uma vez, junto a seus próprios percalços, o deslizar suave das aves pelo horizonte, simbolizando a vida serena que não tem.

A leitura constitui outra atividade referida como prazerosa no precário cotidiano da papeleira mineira: "Li um pouco. Não sei dormir sem ler. Gosto de manusear um livro. O livro é a melhor invenção do homem" (p. 25). Mas muito mais do que a mulher "que lê", Carolina é a mulher "que escreve": "Cheguei em casa, fiz o almoço. Enquanto as panelas fervia eu escrevi um pouco" (p. 20). No Canindé, sua identidade está calcada nesta idiossincrasia: “- Nunca vi uma preta gostar tanto de livros como você" (p. 27), ela ouve de um conhecido que vê como incompatíveis negritude, associada à pobreza, e desenvolvimento cultural. Contrariando o amigo, ela mostra a necessidade da escrita em sua vida precarizada, verdadeiro mecanismo de criação de um plano imaginário de liberdade, bastante próximo da plenitude vislumbrada no voo das aves:

Enquanto escrevo vou pensando que resido num castelo cor de ouro que reluz na luz do sol. Que as janelas são de prata e as luzes de brilhantes. Que a minha vista circula no jardim e eu contemplo as flores de todas as qualidades. [...] É preciso criar este ambiente de fantasia, para esquecer que estou na favela. [...] As horas que sou feliz é quando estou residindo nos castelos imaginários (Jesus, 2007, p. 60-61).

Carolina apresenta-se em suas anotações como uma pessoa cujas necessidades são muito diversificadas. Não há o que servir à mesa, nem sapatos para os meninos irem à escola, nem sabão para o banho, mas ela reivindica o direito de sonhar, de transportar-se para além de sua terrível circunstância concreta de vida. No mesmo sentido, relata que canta e dança com os filhos em busca da alegria possível. Também há menções aos dramas (novelas) que aprecia acompanhar pelo rádio (p. 27), assim como os tangos (p. 147). Ainda que se contraponha veementemente às batucadas dos vizinhos, não sendo festeira e nem apreciadora de álcool, ela declara com contentamento que foi dançar no Carnaval, com sua fantasia de penas (p. 15).

Mesmo composto dessa miscelânea de interesses, Quarto de despejo foi divulgado por muito tempo como obra essencialmente de protesto, cuja 
maior virtude estaria na forte denúncia social que formulava. A conjuntura de politização crescente do início dos anos 60 favorecia esse enquadramento. Já na orelha da primeira edição do livro, o editor Paulo Dantas assim apresentou-o: "Literatura da favela escrita pelo próprio favelado, eis o sentido sincero do livro escrito pela trapeira mineira, radicada em São Paulo". Chamou a atenção o editor na obra o "particular sopro lírico, com invulgares clarões de beleza. Isto é que vence as formas estropiadas de sua ortografia e de sua sintaxe primária, no livro, conservadas pelo seu sabor e singeleza" (Jesus, 1960, s/p).

Nesse primeiro comentário crítico, as dimensões literária e testemunhal estão fundidas, o que não vai se repetir em muitos casos posteriores. O que o pioneiro editor da obra apontou como "particular sopro lírico" do texto foi seguidamente ignorado pelos novos olhares da crítica, que passaram a negar à autora simultaneamente a individualidade da voz e a inventividade da escrita, como a seguir se verá. $\mathrm{O}$ próprio editor na sequência de sua apresentação inaugura essa leitura redutora ao tomar o rico texto dos diários por um "documentário verídico, profundamente corajoso e inocente, um grande testemunho real surgido da sofrida inteligência do povo brasileiro" (Jesus, 1960, s/p).

Os termos "documentário verídico" e "testemunho real" explicitam o entendimento segundo o qual se recusa a dimensão de criação simbólica à produção de Carolina, pouco antes entendida como marcada pelo "sopro lírico" e pelos "clarões de beleza". Parece que o sopro lírico era mesmo apenas um sopro, que se extinguiu depressa, consumindo consigo os clarões de beleza, ausentes nas apreciações críticas posteriores. Na edição de 1983, por exemplo, Fernando Py, afirmou na orelha do livro que este era "um documento vivo de uma época, de uma sociedade, de um estado de coisas" (Jesus, 1983, s/n), como se os diários fossem um produto espontâneo de seu tempo, surgido sem o gesto criador e a marca particular daquela que o gestou.

Anulada como voz autoral, Carolina foi promovida ao longo das diferentes publicações de Quarto de despejo por caracteres do temperamento, como a coragem, por caracteres infantis, como a inocência, e por sua inusitada extração social, pois era a autora "da favela". Quando seu texto mereceu atenção, na maior parte das vezes foi considerado de teor documental, e receberam destaque os erros gramaticais que continha, traços que confirmavam a originalidade do 
livro, marcado, para os que o divulgavam, pelo exotismo da voz popular em grito de protesto contra a fome.

Na edição da Ática de 2007, por exemplo, há um prefácio anônimo datado de 1993 e intitulado "Favela, o quarto de despejo de uma cidade", no qual se lê em destaque colorido: "Não perca! A vida na favela do ponto de vista de quem mora nela. O retrato trágico da fome e da miséria" (Jesus, 2007, s/p). Em seguida, há uma nota dos editores afirmando: "Esta edição respeita fielmente a linguagem da autora, que muitas vezes contraria a gramática, mas que por isso mesmo traduz com realismo a forma de o povo enxergar e expressar seu mundo" (Jesus, 2007, s/p).

$\mathrm{O}$ tom sensacionalista da mensagem fica evidenciado no tom de urgência ("não perca!") com que o "retrato trágico da fome" é anunciado. Mais uma vez o texto de Carolina é caracterizado como mero registro das carências da vida na favela e como portador de inúmeras incorreções gramaticais. Jaime Ginzburg, em artigo sobre o testemunho, escrita marcada pela indissociabilidade das dimensões ética e estética, fornece elementos para a discussão dos critérios de avaliação da qualidade literária da produção de autores subalternos, portadora de evidente teor testemunhal: "O problema do valor do texto, da relevância da escrita, não se insere em um campo de autonomia da arte, mas é lançado no campo abrangente dos direitos civis, em que a escrita é vista como enunciação posicionada em um campo social marcado por conflitos" (Ginzburg, 2010, p. 2).

É possível, então, entender a literariedade como juízo de valor atribuído a um texto pelos sujeitos sociais investidos de autoridade para fazer essa definição, críticos acadêmicos, editores, jornalistas. Estes apresentaram Quarto de despejo como obra feita por uma favelada que escrevia, não por uma escritora. E favelada, segundo a visão corrente, só podia falar sobre favela, assunto que reconhecidamente conhece. Como se o bairro pobre de onde vinha empobrecesse-lhe a escrita, comprometendo sua ficcionalidade. Como se da mulher pobre não se pudesse esperar mais do que o testemunho real da pobreza. Como se seu chão fosse seu teto em termos de alcance literário. Regina Dalcastagnè comenta a respeito desse recorte restrito de leitura:

É como se a sociedade brasileira estivesse disposta a ouvir as agruras de sua vida, e só. Ou como se a alguém como Carolina Maria de Jesus não coubesse mais do que escrever um diário, 
reservando-se o "fazer literatura" àqueles que possuem legitimidade social para tanto, especialmente homens, brancos, de classe média (Dalcastagnè, 2008, p. 96).

O entendimento de Carolina como "autora da favela" foi corrente na crítica até bem pouco tempo. De forma ainda mais redutora, ela foi apresentada em prefácio da edição de 1994, intitulado "A literatura e a fome", como "'porta-voz' da favela", alguém que "ultrapassou os limites individuais e deu voz à coletividade miserável e anônima que habita os barracos e os vãos das pontes nas grandes cidades brasileiras" (Jesus, 1994, p. 169). Não se trata de ultrapassar a individualidade, tratase contrariamente de não atingi-la devido à inserção forçada no anonimato do seu espaço de origem, o coletivo da favela, do qual a autora seria supostamente voz representante.

Michelle Perrot comenta que, na história das mulheres, é comum estas serem referidas "em grupos - fiandeiras, caçadoras clandestinas, arruaceiras, e não como pessoas, como se elas não o fossem, o que coloca o problema do seu reconhecimento individual" (Perrot, 2005, p. 12). Ainda que o âmbito da pesquisa da historiadora seja o das mulheres francesas do século XIX, pode-se perceber que persiste, com Carolina Maria de Jesus no século XX, o triste estigma do feminino diluído em identidade grupal. E neste caso em particular, uma identidade grupal extremamente controversa.

A compreensão da escritora como "porta-voz da favela" é inapropriada, porque Carolina é porta-voz apenas de si mesma, suas anotações são relatos pessoais do seu cotidiano, nos quais utiliza com frequência o termo "os favelados" para referir-se aos vizinhos distanciadamente. Às vezes, a própria autora percebe essa exterioridade ilusória e corrige-se: "Devo incluir-me, porque eu também sou favelada. Sou rebotalho. Estou no quarto de despejo, e o que está no quarto de despejo ou queima-se ou joga-se no lixo" (p. 33). Ainda assim, sua entrada na cena cultural brasileira dos anos 60 e a posterior imagem autoral por meio da qual foi promovida passavam pela identificação com o conjunto dos favelados, mesmo que deles ela buscasse se diferenciar com veemente insistência.

A força vital do imaginário individual contido no texto dos diários é igualmente desconsiderada nesse recorte crítico que toma a autora como parte do todo maior marginalizado. Esse imaginário manifesta-se em formulações muito próprias, estando ligado com frequência à 
apreciação da dimensão estética das coisas mais simples da vida, como cozinhar: "As panelas fervendo no fogo também serve de adorno. Enfeita um lar" (p. 103). A comida tão arduamente buscada, uma vez obtida, é desfrutada física e espiritualmente, tornando-se a verdadeira imagem da felicidade.

Aqueles que tinham poder para julgar a qualidade estética dos diários deixaram soar inapreciada a sede de beleza contida na voz autoral de Carolina. Seu olhar nunca foi domesticado pela feiura da favela, nem pela feiura do lixo que juntava como forma de sustento. Mesmo estando enraizada em um espaço imundo e fétido, sua vista se erguia e alcançava o céu salpicado de estrelas, porque precisava do consolo dessa imagem deslumbrante. A crítica que enquadrou a obra como "brado contra as favelas" (Meyhi e Levine, 1994, p. 25) não ouviu a voz delicada da autora em momentos como aquele em que, dizendose "exótica" ao se perceber vaidosa, ela declarava que "gostaria de recortar um pedaço do céu para fazer um vestido" (p. 33).

Praticamente desdenhado pela crítica nacional, esse universo feminino contido nos diários permanece ainda inexplorado na riqueza de seus elementos. A cidade em que vive é, por exemplo, representada através de peças de roupa: “Oh! São Paulo rainha que ostenta vaidosa a tua coroa de ouro que são os arranha-céus. Que veste viludo e seda e calça meias de algodão que é a favela" (p. 42). Segundo Perrot, a persistência dos trabalhos da casa, das roupas, faz com que "a memória das mulheres [seja] vestida" (Perrot, 2005, p. 38).

Também por meio de referências do espaço doméstico Carolina representa a desigualdade social da cidade: "Eu classifico São Paulo assim: o Palácio é a sala de visita, a Prefeitura é a sala de jantar, a cidade é o jardim. E a favela é o quintal onde jogam os lixos" (p. 31) Há ainda rastros do olhar feminino na forma de representar o sucesso, quando ele se apresenta ${ }^{3}$, em termos de limpeza: “ Eu estou tão alegre. Parece que a minha vida estava suja e agora estão lavando" (p. 174).

Sabe-se que a escrita feminina surge relacionada às necessidades da vida privada, identificando-se com as correspondências ou os diários

\footnotetext{
${ }^{3}$ Publicado pela Livraria Francisco Alves em 1960, Quarto de despejo teve a sua primeira edição de dez mil exemplares esgotada na primeira semana do lançamento. Nove edições foram feitas no Brasil, sem contar a edição de bolso feita em 1976, um ano antes da morte da autora. O livro foi em seguida traduzido para treze línguas e circulou em quarenta países. Carolina Maria de Jesus passou a ser assunto constante de jornais e revistas nacionais e internacionais. O êxito comercial da obra permitiu-lhe comprar uma casa de alvenaria fora do Canindé.
} 
íntimos. Os diários de Carolina Maria de Jesus não se identificam com a esfera familiar apenas, pois discorrem também sobre as dificuldades do trabalho e temas variados, como a política, por exemplo: "Eu quando estou com fome quero matar o Jânio, quero enforcar o Adhemar e queimar o Juscelino. As dificuldades corta o afeto do povo pelos políticos" (Jesus, 2007, p. 34). Ainda assim, o texto é narrado em forma de diário, herança da escrita doméstica feminina. Regina Dalcastagnè é pioneira na identificação do perfil feminino da escrita da autora periférica:

Nesse olhar "de dentro" [da favela] é possível notar uma grande variedade de perspectivas. [...] Tudo, é claro, ajustado por um viés feminino, que olha pela janela do barraco enquanto esquenta a mamadeira das crianças, que observa a mulher apanhando e pensa que é melhor estar sem homem, que ter de parar de escrever para lavar roupa (Dalcastagnè, 2008, p. 98).

Vinculado às questões de mulheres em sua forma diarística e em seu viés essencial, Quarto de despejo se afasta drasticamente delas no que toca à formulação de uma identidade de gênero compartilhada com as demais moradoras da favela. São frequentes no texto as referências ao convívio tumultuado com estas:

As mulheres saíram. Deixou-me em paz por hoje. Elas já deram o espetáculo. A minha porta atualmente é theatro. [...] Elas alude que eu não sou casada. Mas sou mais feliz do que elas. [...]

A noite enquanto elas pede socorro eu tranqüilamente no meu barracão ouço valsas vienenses. [...] Não invejo as mulheres casadas da favela que levam vida de escravas indianas. Não casei e não estou descontente. Os que preferiu me eram soezes e as condições que eles me impunham eram horríveis (Jesus, 2007, p. 17).

Representando suas noites como sendo repletas de "valsas vienenses", enquanto ecoam dos demais barracões os gritos decorrentes das surras frequentes que levam as mulheres casadas, Carolina delineia ao leitor seu isolamento da vida social da favela. Além de não ser casada, a mãe de Vera Eunice tem um temperamento difícil, chama a polícia quando "os favelados" envolvem-se em brigas, em função de bebedeiras, sendo assim constantemente discriminada pelos demais. Reforça o seu estigma social o fato de escrever um livro, cujo tema é alardeado, com intenções muito claras de impor respeito junto aos demais moradores da região, como o diálogo transcrito evidencia: 
- Vou escrever um livro referente a favela. Hei de citar tudo que aqui se passa. E tudo que vocês me fazem. Eu quero escrever o livro e vocês com essas cenas desagradáveis me fornece os argumentos. [...] A Silvia pediu-me para retirar o seu nome do meu livro (Jesus, 2007, p. 20).

Os diários de Carolina funcionam efetivamente como arma de defesa: "Hoje o dia me foi benéfico. As rascoas da favela estão vendo eu escrever e sabe que é contra elas. Resolveram me deixar em paz" (Jesus, 2007, p. 20). Segundo Michelle Perrot, "A mulher autora, esta pretensa literata, é detestada, atrai para si todos os sarcasmos. Uma mulher que escreve, e sobretudo que publica, é uma mulher desnaturada" (Perrot, 2005 , p. 271), vista como a "antítese da feminilidade". Isso porque ao longo de séculos a educação buscou fazer mulheres adaptadas a suas tarefas "naturais" - esposas, mães, donas de casa.

Mais forte ainda é o estigma da escritora que se volta para o próprio bairro em que reside como tema de sua obra, pois nesse caso narram-se cenas da vida dos vizinhos, que se sentem expostos e explorados por aquela que tem o poder de contar, tornando-se alvo da ira dos demais: "Sentei no sol para escrever. A filha da Sílvia, uma menina de seis anos, passava e dizia: '- Está escrevendo, nega fidida!' A mãe ouvia e não repreendia. São as mães que instigam" (p. 28).

Carolina, como se pode ver, é "marginal" em relação aos seus pares, mas compõe com eles um todo que é marginal dentro da estrutura socioeconômica da cidade. Carlos Vogt, em ensaio sobre a obra, compreendeu muito bem a fissura identitária de que Carolina é portadora, apresentando-a simultaneamente como inserida e desajustada em seu habitat social:

De um lado, a autora pertence ao mundo que narra e cujo conteúdo de fome e privação compartilha com o meio social em que vive. Do outro, ao transformar a experiência real da miséria na experiência lingüística do diário, acaba por se distinguir de si mesma e por apresentar a escritura como uma forma de experimentação social nova, capaz de acenar-lhe com a esperança de romper o cerco da economia de sobrevivência que tranca sua vida ao dia-a-dia do dinheiro-coisa (Vogt, 1983, p. 210).

A escrita do livro, fonte de plenitude existencial e motivo de empoderamento social na vila, é uma escrita de cunho eminentemente individual que serve a uma causa muito particular: “É que eu estou 
escrevendo um livro para vendê-lo. Viso com esse dinheiro comprar um terreno para eu sair da favela" (p. 28). O exercício continuado da escrita acaba impedindo a realização amorosa, pois, baseada em argumentos bastante conservadores acerca dos papéis sociais de gênero, a autora justifica a razão de nunca ter casado: “[U]m homem não há de gostar de uma mulher que não pode passar sem ler. E que levanta para escrever. E que deita com lápis e papel debaixo do travesseiro. Por isso é que eu prefiro viver só para o meu ideal" (p. 50).

Dedicando-se com afinco ao seu ideal, Carolina conseguiu publicar Quarto de despejo: diário de uma favelada, tornando-se celebridade mundial devido às vendagens espetaculares da obra, que lhe permitiram mudarse da favela e realizar o sonho de "residir numa casa residível" (p. 40). Importa, no entanto, registrar a fugacidade desse sucesso, decorrência evidente da especificidade do perfil autoral com que ela foi inserida no sistema literário vigente. Após a consagração da estreia, não lhe foi possível manter-se em voga como escritora, pois seu diferencial, baseado na identificação com a favela, esgotou-se ao partir dela. Casa de alvenaria: diário de uma ex-favelada, publicado em 1961, não emplacou no mercado exatamente por essa razão. A novidade que ela era como autora já tinha sido consumida velozmente pelos leitores.

Analisando essa espécie de censura cultural que age de modo implícito, atuando em favor das regras dominantes e afastando certos sujeitos sociais do direito à plena expressão simbólica, José Carlos Sebe Bom Meihy explica o caráter provisório do acesso que foi franqueado a Carolina na cena cultural dos anos 1960:

Paradoxalmente, a notabilidade derivada dos diários afogou outras manifestações literárias da esfingética escritora semianalfabeta da São Paulo que então se orgulhava de ser a "cidade que mais crescia no mundo". O restante de seu vasto legado composto por uma obra de mais de cinco mil páginas manuscritas contendo: quatro romances, cerca de trezentos poemas, três peças teatrais, provérbios - foi, contudo, silenciado. Como se o sucesso lhe fosse uma licença momentânea, quase que a provar a interação do Brasil no quadro das democracias, Carolina aprendeu o sentido da volta ao lugar da pessoa não prezada socialmente (Meihy, 2002, p. 333).

Passada a euforia do sucesso, autora devia voltar humildemente ao anonimato da vida pregressa e ainda reconhecer que nem mesmo no 
auge da fama tivera reconhecimento cultural como artista, tendo sido apenas a sombra de uma escritora, cuja imagem engessada rendera bons lucros no mercado editorial.

A censura ao direito de sonhar nos escritos de Carolina, e a decorrente restrição à sua plena cidadania autoral possivelmente se devem às diferentes instâncias de mediação pelas quais o texto dos diários passou até chegar ao público. O jornalista Audálio Dantas, responsável pela apresentação e edição dos dois diários ressalta ter sido pequena sua participação na organização dos volumes: “Conservei a linguagem e a ortografia da autora, sem alterar nada. No trabalho de compilação, houve cortes de grandes trechos, todos sem maior significação. Ficou o essencial, o importante [...]" (Dantas, 1961, p. 9).

Audálio conserva a linguagem e a ortografia originais, mas sabe que poderia alterá-las, caso o quisesse, pois tem autoridade para fazê-lo. O jornalista parece não perceber que "importante" ou "desimportante" são juízos de valor e não termos de sentido incontroverso e que, portanto, os livros que chegaram ao público configuram a "sua" versão dos diários de Carolina. A estudiosa Elzira Divina Perpétua comparou o manuscrito original de Quarto de despejo e o texto do livro publicado, concluindo que os acréscimos, substituições e supressões realizadas tiveram por fim construir uma identidade autoral homogênea, baseada centralmente na inserção social daquela que escrevia, cuja voz teria sido destituída de meios-tons problemáticos: “Depois de ler Quarto de despejo, sabemos que ele encena a vivência de uma mulher, negra e favelada, mas não travamos contato com a imagem que Carolina produziu de si mesma nos seus manuscritos: complexa, multifacetada, proteiforme" (Perpétua, 2003, p. 80).

Ainda que tais aspectos estejam presentes na versão editada pelo jornalista, como se apontou ao longo deste texto, Elzira afirma que eles teriam sido bastante diluídos, aspecto atribuído à necessidade de configurar uma imagem verossímil da autora como personagem "do povo". Sem acesso aos manuscritos originais microfilmados, que constam do acervo da Biblioteca Nacional, e dispondo apenas do contraponto de Meu estranho diário, versão de José Carlos Sebe Bom Meihy e Robert Levine de alguns trechos do texto original, o que se pode assegurar é que a Carolina que se conhece é o produto final de uma longa série de processamentos. Quem era ela e o que pretendia 
com a escrita a que se dedicava com tanto afinco ainda são questões ainda em aberto.

O discurso do próprio Audálio Dantas, na apresentação do segundo diário, definindo-o como um "registro de grande valor humano e de grande valor como contribuição para estudo sociológico" (Jesus, 1961, p. 6), reforça os preconceitos difundidos desde a estreia de Carolina, raríssimas vezes apontada como escritora. Na condição de padrinho, ele define que era já tempo de a papeleira-autora despedir-se da carreira:

Agora você está na sala de visitas e continua a contribuir com este novo livro, com o qual você pode dar por encerrada a sua missão. Conserve a humildade, ou melhor, recupere aquela humildade que você perdeu um pouco - não por sua culpa - no deslumbramento das luzes da cidade. Guarde aquelas "poesias", aqueles "contos" e aqueles "romances" que você escreveu (Dantas, 1961, p. 9).

Chama a atenção a maneira como o repórter se refere às obras ainda não publicadas de Carolina, entre aspas, sugerindo não serem efetivamente o que ela presumia que fossem. Mas o mais importante de seu texto é o aviso de que já era chegada a hora de encerrar a "missão" autoral. Alçada ao sucesso quando assim foi decidido por outrem, Carolina ouvia naquele momento que era chegada a hora de despedirse, também por vontade alheia.

Oculta por camadas variadas de mediação, é difícil definir a identidade de Carolina, que chega ao público coberta por muitos véus. De sua voz, somente nos chegam ecos desencontrados. Possivelmente por essa razão José Carlos Sebe Bom Meihy tenha intitulado de Carolina Maria de Jesus: emblema do silêncio o artigo constante da Biblioteca Virtual de Direitos Humanos da USP. O silêncio a que se refere o estudioso não é identificado com a ausência de fala, mas com uma fala sempre acessível pela via da tradução autorizada, que faz chegarem ao público versões particulares da poética com que a autora representou originalmente seu cotidiano.

A própria escritora protesta acerca do engessamento identitário a que é submetida pelos especialistas: "Alguns críticos dizem que sou pernóstica quando escrevo - 'os filhos abluíram-se.' Será que preconceito existe até na literatura? $\mathrm{O}$ negro não tem direito a pronunciar o clássico?" (Jesus, 1961, p. 63-64). Atribuindo ao traço étnico a censura recebida pelo uso "do clássico" em sua linguagem, 
Carolina demonstra aflição diante do perfil caricato de "autora favelada" que lhe é imposto, cerceando seu direito de usar o vocabulário pouco usual que de fato conhece, impedindo-a de ser ela mesma: "Dá a impressão que sou uma folha ao sabor das ondas" (Jesus, 1961, p. 154). Regina Dalcastagnè analisa a circunstância autoral de vozes subalternas:

O silêncio dos marginalizados é coberto por vozes que se sobrepõem a ele, vozes que buscam falar em nome dele, mas também, por vezes, é quebrado pela produção literária de seus próprios integrantes. Mesmo no último caso, tensões significativas se estabelecem: entre a "autenticidade" do depoimento e a legitimidade socialmente construída da obra de arte literária, entre a voz autoral e a representatividade do grupo e até entre o elitismo do próprio campo literário e a necessidade de democratização da produção artística (Dalcastagnè, 2008, p. 78).

O "caso" de Carolina ilumina perfeitamente o embate cultural discutido pela estudiosa da literatura contemporânea, pois seu relato é considerado autêntico, porém destituído de legitimidade literária, ainda que Carolina buscasse escrever como todos escreviam, empenhando-se em construir um discurso sofisticado possivelmente para ocultar as marcas de sua precária formação. Exatamente em virtude do prestígio que o código ideológico e linguístico dominante tem no imaginário dos segmentos menos privilegiados socialmente, Gayatri Spivak encerra seu estudo acerca das perspectivas da fala destes na conjuntura pós-colonial com uma afirmação categórica e impactante: “O subalterno não pode falar" (Spivak, 2010, p. 126).

As considerações da estudiosa indiana no trabalho intitulado Pode o subalterno falar? são de absoluta pertinência dentro da discussão sobre a escrita de Carolina Maria de Jesus. Diz Spivak: "Se o discurso do subalterno é obliterado, a mulher subalterna encontra-se em uma posição ainda mais periférica pelos problemas subjacentes às questões de gênero. [...] O subalterno não tem história e não pode falar, o sujeito subalterno feminino está ainda mais profundamente na obscuridade" (Spivak, 2010, p. 14-15).

Enfrentando restrições sociais, políticas e culturais, Carolina resiste e fala. Fala da sua maneira, precisando, segundo o código vigente, que seu texto peculiar seja montado, com grandes trechos, julgados "desimportantes", sendo suprimidos na versão final e masculina da 
obra. Precisando ainda que inúmeras notas esclareçam a presença de "erros", de inteira responsabilidade da autora semialfabetizada, em sua escrita, ou ainda que a "traduzam" em versão mais limpa e culta. Precisando igualmente de agentes que lhe concedam a palavra e autorizem seu discurso tosco. Rompendo drasticamente com o silenciamento a que é conduzida pela cultura hegemônica uma mulher subalterna, ela escreve.

Como escreve na zona de obscuridade a que se refere Spivak, Carolina carece ser iluminada por uma série de vozes mais autorizadas do que a dela a falar. Ela mesma demonstra ter entendimento da própria situação subalterna, em que pese o sucesso de vendas da obra de estreia, e por isso protesta: “Triste glória que não me deixa ter vontade própria. Quero ser eu. Fizeram-me desviar de tudo que pretendia quando morava na favela e ansiava deixar o barraco. O que sou agora? Um boneco explorado e me recuso a isso" (Jesus, 1996, p. 27). Carolina vê seu discurso deslizar e adquirir sentidos imprevistos, descolando-se de si e de sua história, o que confirma tristemente a avaliação de Gayatri Spivak.

Carolina Maria de Jesus foi uma mulher livre, que não se sujeitou a maridos ou a quaisquer autoridades. Portadora de uma causa pessoal, nunca se engajou em nenhum movimento político, nem mesmo contestou as raízes da precariedade social em que viveu. Falou de si, construindo-se em seu habitat periférico por meio da atividade da escrita. Sempre se viu como autora, desdobrando, a partir desse papel, seu perfil identitário feminino mais essencial, um perfil que cabe ainda ser mais bem delineado. Deixou-nos dois diários cujas edições reconfiguraram sua criação, tornando-se um misto de voz e silêncio. ${ }^{4}$

As palavras sempre foram a única arma de que dispunha, porque constatou desde a infância que eram "afônicos" os negros (Jesus, 2007b, p. 40) e os pobres (Jesus, 2007b, p. 248) que conhecia. As mulheres poderiam ser agregadas ao grupo dos "sem voz" por ela identificado, mas essa consciência de gênero ela não possuía. Dedicou-se com afinco a romper com a herança de afonia recebida, ciente das dificuldades que encontraria nessa busca incerta: "Eu estava sentada ao sol escrevendo e

\footnotetext{
${ }^{4}$ Deixou ainda o romance Pedaços de fome, a autobiografia Diário de Bitita e a Antologia pessoal, contendo poemas escritos ao longo de décadas. Manuscritos, deixou peças, aforismos e outros textos nunca publicados. Nenhum desses trabalhos está em discussão neste artigo, por isso não são referidos.
} 
supliquei, oh meu Deus! Preciso de uma voz" (Jesus, 1996, p. 51). A presença de Carolina Maria de Jesus no cenário literário nacional, bem pouco aberto às vozes dos segmentos excluídos (ver Dalcastagnè, 2003), 5 torna esse espaço, que é um espaço em disputa, mais representativo e mais democrático. E torna a leitura uma experiência mais significativa para aqueles que buscam encontrar nela não o que já lhes é familiar, mas o que lhes é desconhecido, o outro, com toda a carga de dor, sofrimento e a capacidade de beleza de que é portador.

\section{Referências}

CANDIDO, Antonio (2004). O direito à literatura. In: Vários escritos. São Paulo: Duas Cidades; Rio de Janeiro: Ouro sobre Azul.

DALCASTAGNE, Regina (Org.) (2008). Vozes e sombras: representação e legitimidade na narrativa contemporânea. In: Ver e imaginar o outro: alteridade, desigualdade, violência na literatura brasileira contemporânea. Vinhedo: Horizonte.

DALCASTAGNÈ, Regina (2003). Sombras da cidade: o espaço na narrativa contemporânea brasileira. Ipotesi, Juiz de Fora, v. 2, n. 7, p. 11-28.

DANTAS, Audálio. Casa de alvenaria: História de uma ascensão social. In: JESUS, Carolina Maria (1961). Casa de alvenaria: diário de uma ex-favelada. Rio de Janeiro: Francisco Alves.

GINZBURG, Jaime (2010). Linguagem e trauma na escrita do testemunho. Conexão letras, Porto Alegre, n. 3, p. 61-66. Disponível em: <http://www.msmidia.com/conexao/3/cap6.pdf>. Acesso em: 8 abr. 2013.

JESUS, Carolina Maria de (1960). Quarto de despejo: diário de uma favelada. 6. ed. São Paulo: Francisco Alves.

JESUS, Carolina Maria de (1961). Casa de alvenaria: diário de uma ex-favelada. Rio de Janeiro: Francisco Alves.

JESUS, Carolina Maria de (1983). Quarto de despejo: diário de uma favelada. 10. ed. São Paulo: Francisco Alves.

JESUS, Carolina Maria de (1994). Quarto de despejo: diário de uma favelada. 3. ed. São Paulo: Ática.

\footnotetext{
${ }^{5}$ No texto, fala-se de ausência de segmentos excluídos no âmbito das personagens das narrativas brasileiras contemporâneas. Parto dessa consideração para apreciar a importância da presença destes segmentos no âmbito da criação literária.
} 
JESUS, Carolina Maria de (1996). Meu estranho diário. Organização de José Carlos Sebe Bom Meihy e Robert M. Levine. São Paulo: Xamã.

JESUS, Carolina Maria de (2007). Quarto de despejo: diário de uma favelada. 9. ed. São Paulo: Ática.

MEIHY, José Carlos Sebe Bom; LEVINE, Robert (1994). Cinderela negra: a saga de Carolina Maria de Jesus. Rio de Janeiro: Editora da UFRJ.

MEIHY, José Carlos Sebe Bom (1998). Carolina Maria de Jesus: emblema do silêncio. São Paulo: Biblioteca Virtual de Direitos Humanos da Universidade de São Paulo. Disponível em: <www.cefetsp. br/edu/eso/cidadania/meihyusp. html>. Acesso em: 8 abr. 2013.

MEIHY, José Carlos Sebe Bom (2002). Subversão pelo sonho: a censura cultural nos diários de Carolina Maria de Jesus. In CARNEIRO, Maria Luiza Tucci (Org.). Minorias silenciadas: história da censura no Brasil. São Paulo: EDUSP, Imprensa Oficial do Estado, Fapesp.

PERPÉTUA, Elzira Divina (2003). Aquém do Quarto de despejo: a palavra de Carolina Maria de Jesus nos manuscritos de seu diário. Estudos de literatura brasileira contemporânea, Brasília, n. 22, p. 63-83.

PERROT, Michele (2005). As mulheres ou os silêncios da história. Tradução Viviane Ribeiro. Bauru: Edusc.

SPIVAK, Gayatri Chakravorty (2010). Pode o subalterno falar? Tradução de Sandra Regina Goulart Almeida, Marcos Pereira Feitosa, André Pereira Feitosa. Belo Horizonte: Editora UFMG.

VOGT, Carlos (1983). Trabalho, pobreza e trabalho intelectual. In: SCHWARZ, Roberto (org.). Os pobres na literatura brasileira. São Paulo: Brasiliense.

Recebido em abril de 2014.

Aprovado em maio de 2014.

\section{resumo/abstract}

\section{A censura ao direito de sonhar em Quarto de despejo, de Carolina Maria de Jesus}

Luciana Paiva Coronel

O trabalho parte da consideração da literatura como direito fundamental do homem, passando a analisar a dimensão literária e o imaginário feminino presentes em Quarto de despejo, de Carolina Maria de Jesus, a fim de evidenciar a 
habilidade da autora na criação de representações muito ricas do seu cotidiano miserável, e com isso contestar a consideração usual do texto como sendo um mero documentário sobre a fome no Brasil dos anos 50. Procurando evidenciar a existência de uma censura implícita por parte dos mediadores culturais, encarregada de impedir que uma mulher subalterna possa ser considerada escritora, e relegando-a ao âmbito do mero protesto, conclui-se que a palavra de Carolina, eco de muitas vozes autorizadas, enriquece a cena literária brasileira contemporânea, dando-lhe maior representatividade.

Palavras-chave: direitos humanos, acesso à literatura, escrita subalterna, cidadania autoral.

\section{Censorship of the right to dream in Beyond all pity, by Carolina Maria de Jesus}

\section{Luciana Paiva Coronel}

This study is based on the understanding of literature as a fundamental human right. It analyses the literary dimension and the feminine imagery that are found in Beyond all pity by Carolina Maria de Jesus. Our goal is to highlight the author's skill to create resourceful representations of her miserable daily routine and through this oppose to the usual perception of her text as a bare documentary on Brazil's starvation in the 1950s. We tried to point out that there was some implicit censorship among cultural mediators to prevent a subaltern woman from being seen as a writer, so that she would only find a place in the mere protest scene. Therefore, we understand that Carolina's work found echo of many authorized voices and thus enriches Brazilian contemporary literary scene with greater representativeness.

Keywords: human rights, access to literature, subaltern writing, authorial citizenship. 